\title{
How to measure food loss and waste? A material flow analysis application
}

\author{
Vera Amicarelli, Christian Bux and Giovanni Lagioia \\ Department of Economics, Management and Business Law, University of Bari, \\ Bari, Italy
}

\begin{abstract}
Purpose - The purpose of this paper is to measure food loss and waste by material flow analysis (MFA) tool. Applying this methodology, the authors estimate wastage-related losses and discuss opportunities for more circular and sustainable practices in the Italian potato industry.

Design/methodology/approach - MFA is applied to two specific typologies as follows: ready-to-eat (chips) and dried potato products produced in Italy. The analysis refers to the year 2017 as the complete dataset useful for this study includes measurements until this year. A bottom-up and top-down mixed approach is applied, and functional unit refers to $1 t$ of potatoes consumed as final product.

Findings - MFA is applied to quantify and qualify material balance associated with $1 t$ of potatoes consumed as final product. In Italy, in 2017, more than 22,000 $t$ of fresh tubers were lost, including 3,500-4,800 $t$ of starch, equivalent to 52,800-72,600 GJs. Moreover, fewer than 23,000 $t$ of skins and scraps were produced within industrial plants, not available for food but suitable for animal feed (dry skins are an excellent carbohydrates source in cattle and poultry feed), starch industry and bioenergy production (biogas and/or bioethanol).

Originality/value - This research is one of the few studies proposing MFA methodology as a tool to measure food waste. This analysis shows its utility in terms of food waste quality/quantity evaluation, supporting both company management and policymakers.
\end{abstract}

Keywords Sustainability, Food waste, Food loss, Italian potato industry, Material flow analysis

Paper type Research paper

\section{Introduction}

The global phenomenon of food loss and waste has increased by more than $50 \%$ (in weight) in recent years (Hall et al., 2009). According to FAO (2017, 2018, 2019c), International Food Policy Research Institute (2019) and Gustavsson et al. (2011) data, each year more than 1.3bn $t$ of food on average are thrown away, equal to over a third of global production. Food is wasted along the whole food supply chain, recording several differences in quantity and quality from one region to another.

There is still no internationally accepted definition of food loss and food waste. According to FAO (2011), food losses or waste "are the masses of food lost or wasted in the part of food chains leading to edible products going to human consumption". This means that food originally designated for human consumption but later excluded from human nutrition, even if reused for other purposes - such as energy recovery or animal feed - is considered food loss or waste. FUSIONS (2016a) does not distinguish between food loss and food waste, stating that the latter is "fractions of food and inedible parts of food removed from the food supply chain to be recovered or disposed" (e.g. composting, anaerobic digestion, bioenergy production).

On average, more than $160 \mathrm{~kg} / \mathrm{capita}$ of food are thrown away annually from agricultural production to the distribution and retail stages, ranging from the highest quantity in Latin

(c) Vera Amicarelli, Christian Bux and Giovanni Lagioia. Published by Emerald Publishing Limited. This article is published under the Creative Commons Attribution (CC BY 4.0) licence. Anyone may reproduce, distribute, translate and create derivative works of this article (for both commercial and non-commercial purposes), subject to full attribution to the original publication and authors. The full terms of this licence may be seen at http://creativecommons.org/licences/by/4.0/legalcode 
$\mathrm{BFJ}$

123,1

68

America (200 kg/capita) to the lowest in South and Southeast Asia (100 kg/capita). However, the widest differences between regions occur at the consumption stage (hospitality and household level), where consumer habits play a fundamental role (Fiore et al., 2017). The highest value has been recorded in North America and Oceania (110 kg/capita), and the lowest in sub-Saharan Africa (Bräutigam et al., 2014; FAO, 2019b; Hodges et al., 2010; Pellegrini et al., 2019; Philippidis et al., 2019).

The European Union (EU) generates more than $85 \mathrm{~m}$ tons (Mt) of food waste, corresponding to approximately $170 \mathrm{~kg} /$ capita (more than $20 \%$ of total $\mathrm{EU}$ food production). Of that amount, $9 \mathrm{Mt}$ are wasted at the agricultural stage, $17 \mathrm{Mt}$ at processing, $4 \mathrm{Mt}$ at distribution and retail, 10 Mt in hospitality services (hotels, restaurants, catering) and over $45 \mathrm{Mt}$ at households. This means that over $65 \%$ of EU's food waste occurs at final consumption, while the agricultural and harvest stages record only $10 \%$ of the total quantity wasted (FAO et al., 2018; FUSIONS, 2016a, b; McCarthy et al., 2018; World Hunger Education Service, 2016). The approximate associated costs of food waste were over $€ 700 \mathrm{bn}$ in developed countries and under $€ 300 \mathrm{bn}$ in developing ones in 2017, based on an average value of $1.65 € / \mathrm{kg}$ (FAO, 2017, 2018). For instance, the United States records more than $€ 190 \mathrm{bn}$ in associated costs each year, while the EU records approximately $€ 140 \mathrm{bn}$ (of which about $€ 100 \mathrm{bn}$ are generated just in households and hospitality services) (Barrett, 2010; FUSIONS, 2016a, b; World Hunger Education Service, 2016; McCarthy et al., 2018; FAO, 2019a, c). Italian food waste is roughly equal to $8.78 \mathrm{Mt}$ (149 kg/capita) corresponding to less than $€ 15 \mathrm{bn}$ in costs (approximately $10 \%$ of EU total economic loss) (European Commission, 2010; Notarfonso et al., 2015). Differences between countries are mainly due to local economic, social, industrial and technological development.

In the last decade, food loss and waste have become a topic of growing environmental, social and economic interest. Recently, a plethora of studies have been published on the topic. Several authors have examined the problem in terms of consumer behavior (Fiore et al., 2017), investigating the antecedents affecting food waste at retail (De Moraes et al., 2020; GoodmanSmith et al., 2020) and households (Setti et al., 2018). Others have studied the role of agricultural development (Galford et al., 2020) to reduce food loss and waste in terms of environmental protection (Read et al., 2020) and public safety (Kasza et al., 2019), while only a few have focused on the role of industrial practices ( $\mathrm{Ng}$ et al., 2020) and open innovation (Galanakis, 2020). In terms of economic impact, some studies tried to develop a cost model to calculate monetary losses (Fiore et al., 2015). However, the noncomparability of such studies due to the different estimation methods applied draws attention to the key role played by food waste measurement tools.

The aim of this paper is to adopt the material flow analysis (MFA) methodology to measure and quantify material input and output associated with food waste in the Italian potato industry in 2017, so as to improve the efficiency of natural resources utilized, reduce waste production and/or shift the sector toward circular and more sustainable models of development. MFA is applied to two specific typologies as follows: ready-to-eat (chips) and dried potato products. The authors selected this industrial sector as potato is the fifth most cultivated crop after sugar cane, maize, wheat and rice and one of the most important basic food. It is cultivated in about 130 countries and has become a crucial food both for its direct and indirect use in human diet in the European countries (Eriksson et al., 2016; FAOSTAT, 2019; Eurostat, 2020). The results achieved show the utility of MFA in terms of food waste minimization, supporting both company management and policymakers. To complete the analysis, the authors propose a monetary cost evaluation related to the Italian potato industry.

\section{Food waste measurement: literature review}

Several studies conducted by either international organizations or academic or private researchers or companies have focused on food waste measurement. These quantitative analyses have been conducted at macrolevel (global) (Ju et al., 2017; FAO, 2019a, b), mesolevel 
(regional) (Monier et al., 2010; Fabi and English, 2018) and microlevel (Augustin et al., 2020) and been applied to the whole food chain (FUSIONS, 2014; Martin-Rios et al., 2018) or single stages (Parfitt et al., 2010; Elimelech et al., 2018; Silvennoinen et al., 2019).

The FUSIONS project (2014) before and the European Commission (OJEU, 2019) later provided a state of the art on waste measurement methodologies, assessing five main common methods, described below:

(1) Diaries refer to a single person or group of people (e.g. families, students) asked to calculate and self-report the amount of food loss and waste occurring in their daily life (e.g. at home, in restaurants). However, literature (Sharp et al., 2010) highlights difficulties in participants' recruitment, high dropout rates and potential risk of selfselection as well as poor data quality.

(2) Direct measurement (weighing or volumetric assessment) embraces numerous methods with a direct count and/or measurement of food loss and waste weight. Generally, such methodologies produce the most accurate data, but they require high costs, time and expertise when food loss and waste occur varying according to the stage of the supply chain.

(3) Interviews and surveys are cost-effective ways to estimate food loss and waste, but their results are generally not as accurate as those of other measurement methodologies, being mainly influenced by people's memory (Van Herpen et al., 2016). They yield qualitative information about causes of food loss and waste and behavior attitudes, reaching a wide range of individuals and/or public institutions.

(4) Mass balance measurement calculates food loss and waste on the basis of an inputoutput analysis (e.g. difference between raw materials entering a process and final products sold to consumers). One of the main methodologies is represented by MFA, but its main limits are related to data gaps and waste coefficients assumptions (Caldeira et al., 2019).

(5) Waste composition analysis consists of the physical separation, weighing and categorization of wastes. It helps in determining the quantity of food loss and waste and its quality in terms of food typology, distinguishing between edible and inedible food. Though, it requires specific knowledge, is time-consuming for the researchers and investigates only those waste put out for collection, without considering those disposed or reused for other purposes (Lebersorger and Scheiner, 2011; Parizeau et al., 2015).

One more methodology included only in the FUSIONS project (2014) is proxy data, which is useful for filling in data gaps or deficits when measurement or approximation is not possible or reliable and when budget is limited.

A brief review of all six said methodologies has been performed using Science Direct research database (www.sciencedirect.com), combining the words "food loss" or "food waste" with "measure," "quantification," "quantity" and "methodology", among studies and research published over the last decade (2010-2019) that contain them in the title and/or abstract and/ or keywords. The results related to each combination are recorded in Table 1.

In addition, three more documents recommended by experts were added to this review. From the large number of articles corresponding to the review criteria, only a few (30 articles) were selected so as to be in line with the objective of the present study: the analysis of food waste measurement methodologies within practical experiences. Table 2 illustrates these studies, classified by methodology applied and boundaries considered. Most of the studies combine two or more of them, with proxy data especially recurring, and only four of them propose an MFA methodology. 
BFJ 123,1

70

\section{The Italian potato industry}

Worldwide, potatoes (Solanum tuberosum L.) represent the fifth-highest crop production equal to over $370 \mathrm{Mt}(20 \mathrm{~m}$ ha) - after sugar cane, maize, wheat and rice. With approximately $115 \mathrm{Mt}$ (roughly $30 \%$ of global production), Europe is the second-largest producer of such crops after India, which produces over 185 Mt (Lagioia et al., 2020). Approximately half of worldwide production is consumed fresh as table potatoes. The rest is processed into potatobased products, starch for industry, ingredient for other final products and animal feed or reused as seed tubers for growing future seasons' potato crops. As a raw material in the food processing industry, potatoes are used for ready-to-eat (chips), precooked (French fries) and dried products (potato flour, flakes or granules), snacks and other food (ready-prepared meals, salads, etc.) (European Commission, 2007).

The appropriate pedoclimatic conditions in Italy ensure a relatively uninterrupted availability of potatoes throughout the seasons. In 2017, national production reached $1.06 \mathrm{Mt}$ on harvested land of more than 34,505 ha, with an annual yield equal to $30 \mathrm{t} /$ ha. More than $60 \%$ of cultivated land (21,600 ha) was irrigated and approximately $30 \%$ of that by use of aqueduct or other irrigation consortium water (6,300 ha) (Istat, 2014, 2020a). The quantity of collected potatoes was slightly lower than the harvested quantity, with an amount of less than $1.02 \mathrm{Mt}(-3.8 \%)$ (Istat, 2020a). More than $70 \%$ of Italian harvested potatoes are represented by main crop potatoes, designated to fresh market $(75-80 \%)$ and industrial transformation (20-25\%) (ISMEA, 2003; MIPAAF, 2012; Istat, 2020b). Istat (2020b) estimates that over $235,000 t$ of potatoes are destined to ready-to-eat production and over 2,500 $t$ to dried one. Early potato cultivation covers the remaining $30 \%$ of the dedicated harvest area in Italy (Istat, 2020a). Among main crop potatoes, the quota reserved for food manufacturing is increasing, while the demand for fresh food is declining. This trend is mainly due to consumer behavior, lifestyle changes (busy life, outdoor consumption) and the development of special products often linked to local traditions and territories (Galati et al., 2019; Tarabella et al., 2019).

Across the whole potato value chain, 15-24\% gets lost during agricultural production, $1-2 \%$ during processing, $13-27 \%$ in distribution and retail stages and $13-15 \%$ at private households and through hospitality (Barilla Center for Food and Nutrition, 2012; Janssens et al., 2013; Willersinn et al., 2015; Schneider et al., 2019). However, other studies (Caldeira et al., 2019) have calculated different food loss and waste rates as follows: $2-3 \%$ during agricultural production, $4-5 \%$ during processing, $1-2 \%$ in distribution and retail stages and $13-15 \%$ at households and through food services.

\section{Materials and methods}

\subsection{MFA}

The MFA has been successfully applied at different levels such as single national economic systems (Jacobi et al., 2018), single industrial sectors (De Marco et al., 2009) and single

\begin{tabular}{|c|c|c|c|}
\hline \multicolumn{3}{|c|}{ Combination } & \multirow{2}{*}{$\frac{\text { Number of studies and research published }}{677}$} \\
\hline Food loss & And & measure & \\
\hline & & quantification & 424 \\
\hline & & quantity & 178 \\
\hline & & methodology & 226 \\
\hline \multirow[t]{4}{*}{ Food waste } & And & measure & 342 \\
\hline & & quantification & 331 \\
\hline & & quantity & 309 \\
\hline & & methodology & 360 \\
\hline Source(s): & 1 elabora & e authors & \\
\hline
\end{tabular}

Table 1 .
Number of studies and research published per different combination (2010-2019)

Source(s): Personal elaboration by the authors 


\begin{tabular}{|c|c|c|c|c|c|c|c|c|c|c|c|}
\hline \multirow[b]{2}{*}{ Selected references } & \multirow[b]{2}{*}{ Di1) } & \multicolumn{4}{|c|}{ Methodology } & \multirow[b]{2}{*}{ WCA6) } & \multicolumn{4}{|c|}{ Boundaries } & \multirow{3}{*}{$\begin{array}{r}\text { How to } \\
\text { measure food } \\
\text { loss and waste? }\end{array}$} \\
\hline & & DM2) & IS3) & MB4) & PDR5) & & AP7) & Pr8) & DR9) & Co10) & \\
\hline Abdelaal et al. (2019) & & $\mathrm{X}$ & & & & & & & & $\mathrm{X}$ & \\
\hline Caldeira et al. (2019)* & & & & $\mathrm{X}$ & & & & & $\mathrm{X}$ & & \\
\hline Elimelech et al. (2019) & & $\mathrm{X}$ & & & & & & & & $\mathrm{X}$ & \\
\hline $\begin{array}{l}\text { Garcia-Garcia et al., } \\
\text { 2019* }\end{array}$ & & $\mathrm{X}$ & $\mathrm{X}$ & $\mathrm{X}$ & & & & $\mathrm{X}$ & & & 71 \\
\hline $\begin{array}{l}\text { Poças Ribeiro et al., } 2019 \\
\text { Read et al (2019) }\end{array}$ & & $\mathrm{X}$ & & $\mathrm{Y}$ & $\mathrm{Y}$ & & $\mathrm{Y}$ & $\mathrm{Y}$ & $\mathrm{Y}$ & $\mathrm{X}$ & \\
\hline Sakaguchi et al. (2018) & & & $\mathrm{X}$ & $X$ & $\mathrm{X}$ & & $x$ & $X$ & $\Lambda$ & $\begin{array}{l}\Lambda \\
\mathrm{X}\end{array}$ & \\
\hline Schneider et al. (2019) & & $\mathrm{X}$ & & & & & $\mathrm{X}$ & & & & \\
\hline Silvennoinen et al. (2019) & & $\mathrm{X}$ & & & & & & & & $\mathrm{X}$ & \\
\hline Thamagasorn and & & & & $\mathrm{X}$ & $\mathrm{X}$ & & & $\mathrm{X}$ & $\mathrm{X}$ & & \\
\hline $\begin{array}{l}\text { Pharino (2019) } \\
\text { van Dooren et al. (2019) }\end{array}$ & & & $\mathrm{X}$ & & & $\mathrm{X}$ & & & & $\mathrm{X}$ & \\
\hline van Herpen et al. (2019) & $\mathrm{X}$ & $\begin{array}{l}\mathrm{X} \\
\mathrm{X}\end{array}$ & $\mathrm{X}$ & & & $\mathrm{X}$ & & & & $\begin{array}{l}\mathrm{X} \\
\mathrm{Y}\end{array}$ & \\
\hline $\begin{array}{l}\text { Boschini et al. (2018) } \\
\text { De Laurentiis et al. (2018) }\end{array}$ & & $\mathrm{X}$ & & & $\mathrm{X}$ & & & & & $\begin{array}{l}X \\
X\end{array}$ & \\
\hline $\begin{array}{l}\text { Delley and Brunner } \\
(2018)\end{array}$ & & & $\mathrm{X}$ & & & $\mathrm{X}$ & & & & $\hat{X}$ & \\
\hline Elimelech et al. (2018) & & & $\mathrm{X}$ & & & & & & & $\mathrm{X}$ & \\
\hline Giordano et al. (2018) & $\mathrm{X}$ & & & & & & & & & $\mathrm{X}$ & \\
\hline Hartikainen et al., 2018 & & & $\mathrm{X}$ & & $\mathrm{X}$ & & $\mathrm{X}$ & & & & \\
\hline Szabó-Bódi et al., 2018 & & & $\mathrm{X}$ & & & & & & & $\mathrm{X}$ & \\
\hline Cicatiello et al. (2017) & & & & & $\mathrm{X}$ & & & & $\mathrm{X}$ & & \\
\hline Eriksson et al. (2017) & & $\mathrm{X}$ & & & & & & & & $\mathrm{X}$ & \\
\hline Ju et al., 2017* & & & & $\mathrm{X}$ & & & $\mathrm{X}$ & $\mathrm{X}$ & $\mathrm{X}$ & $\mathrm{X}$ & \\
\hline Tostivint et al. (2017) & & $\mathrm{X}$ & & & $\mathrm{X}$ & & $\mathrm{X}$ & $\mathrm{X}$ & & & \\
\hline $\begin{array}{l}\text { EssonanaweEdjabou } \\
\text { et al. (2016) }\end{array}$ & & $\mathrm{X}$ & & & & & & & & $\mathrm{X}$ & \\
\hline Dias-Ferreira et al. (2015) & & $\mathrm{X}$ & & & & & & & & $\mathrm{X}$ & \\
\hline Love et al. (2015) & & & & & $\mathrm{X}$ & & $\mathrm{X}$ & $\mathrm{X}$ & $\mathrm{X}$ & $\mathrm{X}$ & \\
\hline Silvennoinen et al. (2015) & & $\mathrm{X}$ & & & & & & & & $\mathrm{X}$ & \\
\hline Katajajuuri et al., 2014 & $\mathrm{X}$ & & & & & & & & & $\mathrm{X}$ & \\
\hline Beretta et al., 2013* & & & & $\mathrm{X}$ & & & $\mathrm{X}$ & $\mathrm{X}$ & $\mathrm{X}$ & $\begin{array}{l}\mathrm{X} \\
\mathrm{X}\end{array}$ & Table 2. \\
\hline $\begin{array}{l}\text { Nahman et al. (2012) } \\
\text { Note(s) } \text {. i) Di = Diaries. }\end{array}$ & & & & & $\mathrm{X}$ & & & & & & Selected studies on \\
\hline $\begin{array}{l}\text { Note(s): i) Di = Diaries; } \\
\text { balance; 5) PDR = Proxy d } \\
\text { = Processing; 9) DR = } \\
\text { methodology } \\
\text { Source(s): (Personal elab }\end{array}$ & $\begin{array}{l}\text { 2) DM } \\
\text { ata; 6) } \\
\text { Distrib } \\
\text { oration }\end{array}$ & $\begin{array}{l}=\text { Direct } \\
\text { WCA = } \\
\text { ttion anc } \\
\text { by the a }\end{array}$ & $\begin{array}{l}\text { measu } \\
\text { Naste } \\
\text { d retail } \\
\text { uthors) }\end{array}$ & $\begin{array}{l}\text { rement; } 3 \\
\text { and } 10\end{array}$ & $\begin{array}{l}\text { IS }= \\
\text { on anal } \\
\text { Co }=\end{array}$ & $\begin{array}{l}\text { erviews } \\
\text { is; 7) AP } \\
\text { onsumpt }\end{array}$ & $\begin{array}{l}\text { nd sury } \\
\text { Agric } \\
\text { n; *) S }\end{array}$ & $\begin{array}{l}\text { eys; 4) } \\
\text { ltural } \\
\text { udies }\end{array}$ & coduc & $\begin{array}{l}\text { Iaterial } \\
\text {; 8) Pr } \\
\text { MFA }\end{array}$ & $\begin{array}{r}\text { food waste } \\
\text { measurement by } \\
\text { methodologies and } \\
\text { boundaries } \\
(2010-2019)\end{array}$ \\
\hline
\end{tabular}

products (Lagioia et al., 2012). With regards to food industry, this tool has shown its utility in assessing economic and environmental consequences and in supporting environmental policies and sustainable practices (Kytzia et al., 2004; De Marco et al., 2005; Lagioia et al., 2005; Risku-Norja and Mäenpää, 2007; Beretta et al., 2013). The present research used MFA, defined as "systematic assessment of the state and change of materials flow and stock in space and time" (Brunner and Rechberger, 2017), to support and improve food waste measurement in the Italian potato industry. It applied the analysis to two specific typologies of potato-based products (ready-to-eat and dried potatoes), which represent an interesting portion (approximately 90\%) of the processed potatoes market. This methodology is based on the mass-balance principle, connecting input material and energy flows to output flows in terms of final products and sources, pathways, byproducts and waste (Brunner and Rechberger, 2017; Zaghdaoui et al., 2017). 
$\mathrm{BFJ}$

123,1

72

The simplified process flow diagrams proposed (Figures 1 and 2) are realized based on comparison of company and literature data, and the functional unit adopted is $1 t$ of potatoes consumed as final product. To perform MFA calculations and diagrams the authors utilized Microsoft Excel spreadsheet and freeware STAN 2.6, respectively (Cencic and Kovacs, 2007).

\subsection{Definitions and system boundary}

According to food loss and waste definitions included in Section 1, this analysis considered a single definition that includes both food losses (which mostly take place during agricultural production, postharvest and processing stages due to logistic or technical reasons) and food waste proper (which mainly occurs during distribution, sale and consumption due to human and behavioral variables). Thus, the authors, in accordance with Beretta et al. (2013), refer to both concepts, with the term "food waste" focusing on food originally produced for human

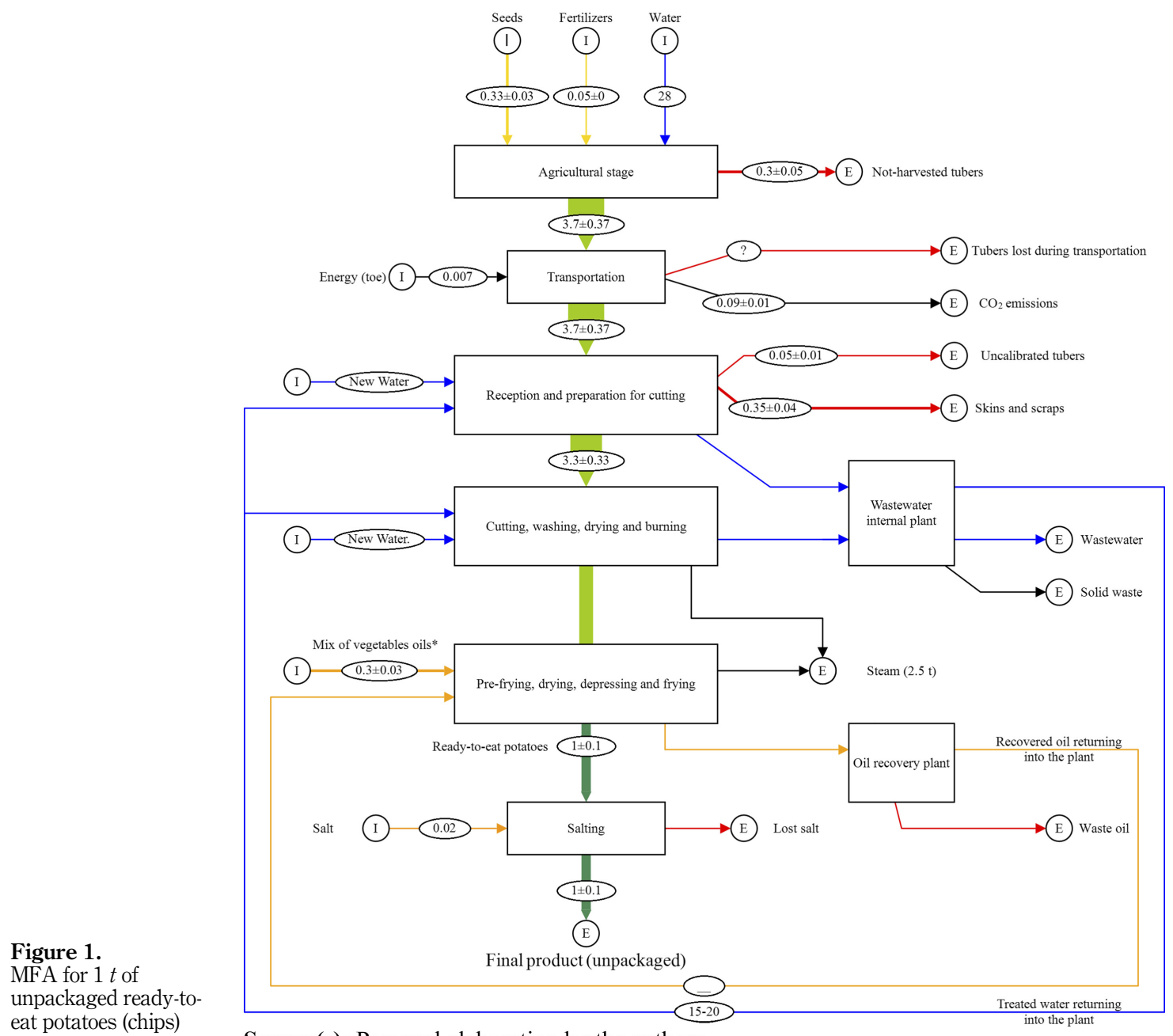

Source(s): Personal elaboration by the authors 

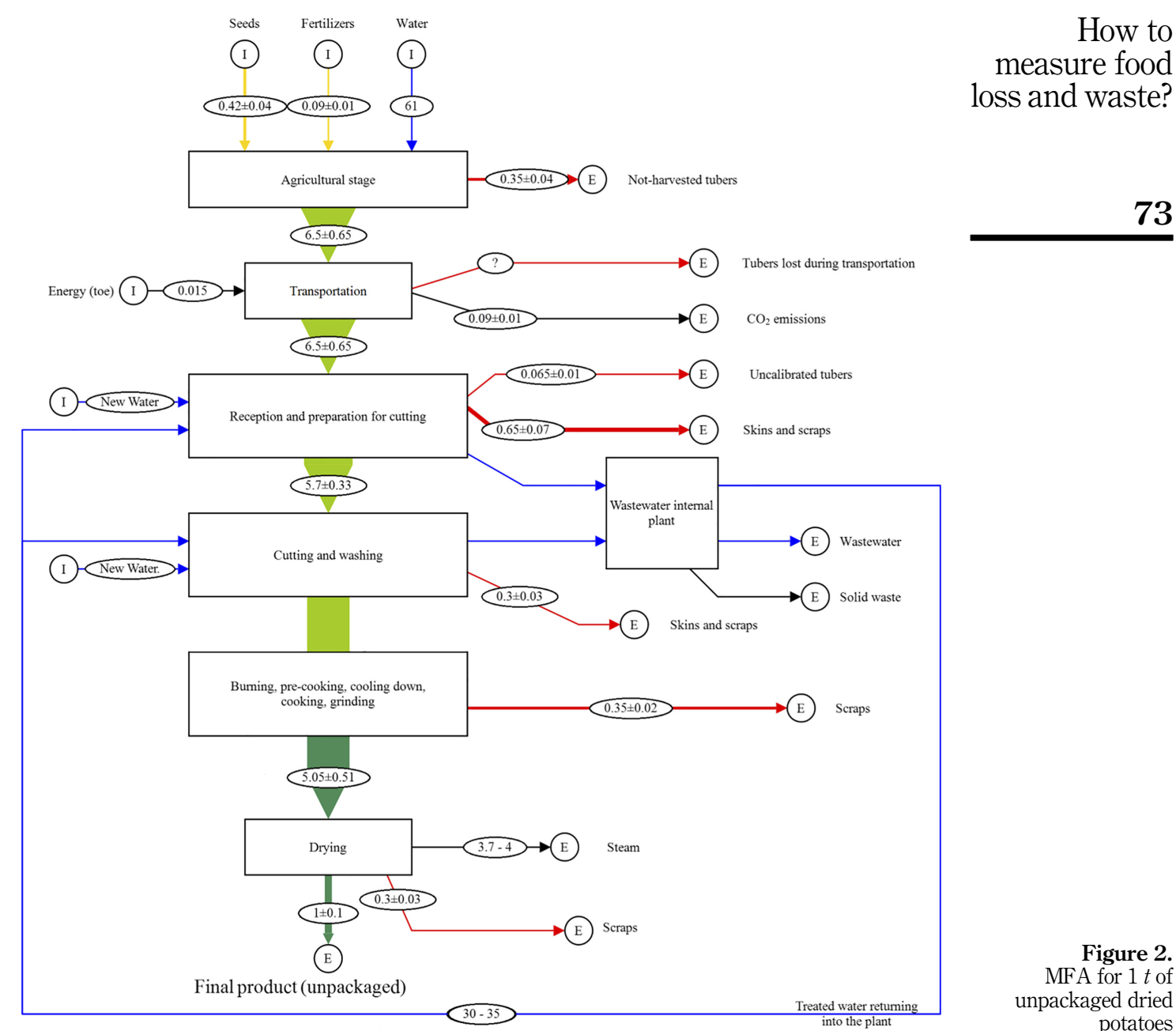

Source(s): Personal elaboration by the authors

Figure 2.

MFA for $1 t$ of unpackaged dried potatoes

consumption but later employed for nonfood uses or energy recovery (e.g. animal feed, bioethanol production, incinerator).

The boundaries cover the food supply chain from the agricultural to the processing stage, without considering distribution and final consumption losses. Agricultural production waste includes losses due to mechanical damage and/or crops sorted out postharvest, while postharvest waste encompasses losses occurring during transport from farms to industrial plants. Processing waste, which represents the widest part among the stages considered, includes losses from meal preparation, food discarded for organoleptic reasons, spillage, degradation and contamination.

\subsection{Data acquisition and general assumptions}

To collect data useful for the objective of this paper, several national and international reports, scientific articles and databases were consulted. Moreover, to fill in the data gaps, one 
$\mathrm{BFJ}$ 123,1

\section{4}

of the most representative Italian potato companies was contacted. The analysis refers to the year 2017 as the complete dataset useful for this study includes measurements until this year.

The analysis was based on more than 237,500 $t$ of potatoes processed by the Italian potatoes industry, which yielded more than 63,000 $t$ of ready-to-eat products (chips) and fewer than $400 t$ of dried potatoes (FAOSTAT, 2019; Istat, 2020a). Frozen potato-based products were excluded from the analysis. The functional unit was $1 t$ of potatoes consumed as final product, and import-export flows were not included. The uncertainty applied in all calculations was $10 \%$.

For the agricultural stage, the authors considered the Italian average potato yield of 2527 tha (Camaggio and Lagioia, 2002; FAOSTAT, 2019; Istat, 2020a), requiring approximately $0.065 \mathrm{t}$ of seed potatoes (Mouron et al., 2016) and a total amount of 14-18 kg of fertilizers per $t$ of tuber, of which are roughly $34 \%$ of $N, 20 \%$ of $K$ and $46 \%$ of $p$ (Hoepli, 1997; Mouron et al., 2016). The average tuber composition is recorded in Table 3 . The estimated water required for the agricultural stage is $9.5 t$ per $t$ of tuber (Mouron et al., 2016).

In terms of transport, energy and related $\mathrm{CO}_{2}$ emissions were calculated based on the latest transport technologies, $100 \mathrm{~km}$ being considered the average distance between land and industrial plants utilizing medium trucks with a weight limit of 7-9 t. $\mathrm{CO}_{2}$ emissions equal to $0.91 \mathrm{~kg}$ of $\mathrm{CO}_{2} / \mathrm{km}$ (EPA, 2018).

The authors did not consider the energy input required during the processing stage in the flowcharts. However, it is estimated that to produce steam and electricity, 7-9 GJs/t and approximately $40 \mathrm{GJ} / t$ are required for ready-to-eat (chips) and dried potatoes, respectively (Camaggio and Lagioia, 2002).

\section{Results}

The entire production of ready-to-eat (chips) and dried potatoes has been divided into two macrosections as follows: agricultural production and processing industry. The flowcharts illustrate that several losses of raw material, energy for transportation and water occur before final consumption.

Figure 1 illustrates the MFA for $1 t$ of unpackaged ready-to-eat potatoes (chips) from the agricultural to the processing stage.

At the beginning of the agricultural stage, main inputs are represented by seed potatoes $(0.33 t)$, fertilizers $(0.05 t)$ and energy for transportation from land to the industrial plant (0.007 toe), producing approximately $0.09 t$ of $\mathrm{CO}_{2}$ and $28 t$ of water. To obtain $1 t$ of final product, $3.7 t$ of tubers are required. During reception and preparation for cutting, uncalibrated tubers $(0.05 t)$ and skins and scraps $(0.35 t)$ are lost. After the cutting, washing, drying and burning stages, chips in a range of $1-1.7 \mathrm{~mm}$ of thickness are obtained. In the prefrying, drying, depressing and frying steps, a mix of vegetables' oils is required in a

Table 3.

Potato average composition

\begin{tabular}{lccccc}
\hline & $\%$ & Minerals & $\mathrm{mg} / 100 \mathrm{~g}$ & Vitamins & $\mathrm{mg} / 100 \mathrm{~g}$ \\
\hline Water & $75-78$ & $\mathrm{Ca}$ & $10-14$ & $\mathrm{~A}$ & Traces \\
Protids & 2 & $\mathrm{p}$ & $53-56$ & $\mathrm{~B} 1$ & 0.1 \\
Carbohydrates & $16-22$ & $\mathrm{Fe}$ & $0.6-0.9$ & $\mathrm{~B} 2$ & $0.02-0.04$ \\
Lipids & $0.1-0.15$ & $\mathrm{~K}$ & $410-570$ & $\mathrm{~B} 5$ & 0.3 \\
Cellulose & $0.4-0.6$ & $\mathrm{Na}$ & $3-7$ & $\mathrm{~B} 6$ & 0.2 \\
Ashes & $0.3-2$ & $\mathrm{Mg}$ & 27 & $\mathrm{C}$ & $15-24$ \\
Fiber & 2 & - & - & $\mathrm{PP}$ & $1.2-1.5$ \\
Energy value & $75-90 \mathrm{kcal}$ & - & - & - & - \\
Source(s): Camaggio and Lagioia, 2002 ; Sablani and Mujumdar, 2006 & & \\
\end{tabular}


range of $0.3-0.4 t$, representing the quantity of oils absorbed by the final product. The potato-to-oil ratio, which must be large enough to ensure a constant oil temperature to avoid critical changes in final product quality, mainly depends on the frying system utilized and on the potatoes' quality and size. Usually, in a continuous frying system such as the one utilized in the analyzed plant, this ratio is 1:20 (Sansano et al., 2015), allowing for improvements in final product quality, the highest yield and huge oil savings (Arslan et al., 2018). In the analyzed plant, cooler oil leaving the frying system arrives at a heat exchanger for reheating and returns to the fryer. After frying, ready-to-eat potatoes are salted with $0.02 t$ of salt.

Roughly 15-20 $t$ of water input are required along the whole industrial production. The major part of this input converges in a wastewater internal plant, where it is treated to be reused inside the plant and to extract starch content, which is utilized for other purposes. Energy used, even if not included in the flowchart, is estimated at 7-9 GJs, of which 0.7-1 GJs are for electricity, and the remaining GJs are for producing steam (approximately $2-3 t$ ).

Figure 2 illustrates the MFA for $1 t$ of unpackaged dried potatoes from the agricultural to the processing stage.

Inputs required for dried potatoes are measured as follows: seed potatoes $(0.42 t)$, fertilizers $(0.09 t)$ and water $(61 t)$, resulting in a more input-intensive process than that for ready-to-eat potatoes. During transportation from land to the industrial plant, 0.015 toe of energy are required, producing approximately $0.09 \mathrm{t}$ of $\mathrm{CO}_{2}$.

At the processing stage, additional water is required in a range of $30-35 t$, which is partially reused in the plant after treatment, while energy required amounts to approximately $40 \mathrm{GJs}$, of which $3 \mathrm{GJs}$ are for electricity and the rest are for producing steam (over 15-20 $t$ ). In terms of output, $0.065 t$ of uncalibrated tubers and over $1.6 t$ of skins and scraps are lost, while more than $3.7 t$ of steam are produced during the drying phase.

The results obtained for the functional unit have been enlarged to the national production of ready-to-eat (chips) and dried potatoes (Table 4). Table 4 records associated monetary losses based on the lowest $(190 € / t)$ and highest $(470 € / t)$ tuber prices in 2017 (ISMEA, 2020).

\section{Discussions}

The MFA methodology, representing a highly detailed "photograph" of the entire food supply chain, allows the measurement of inputs and outputs for each typology of potatobased product. It helps to identify where (specific phase), how much (quantity evaluation) and what kind (quality characterization) of food waste is generated. Potato processing waste is mainly solid, and the amount and quality depend on the variety of the starting potato, the final product obtained and the technology used. The main components of potato waste are as follows:

(1) Raw pieces, differing in size, from entire potatoes to small fragments;

(2) Raw pulp, skin and scraps and pulp from starch separation and

(3) Cooked pulp, mainly dispersed in the wastewater.

Potato peel waste has high starch content ( $52 \%$ of dry weight) and is a good source of vitamin $\mathrm{C}$, vitamin $\mathrm{B}_{6}$, copper, potassium, manganese and dietary fiber. It also contains a variety of phytonutrients, which are a natural source of antioxidants that help prevent cellular deterioration of the body.

Currently, potato waste is mainly used as animal feed and fertilizer. For instance, dry potatoes' skins are an excellent source of carbohydrates in cattle and poultry feed. To avoid the expensive drying costs, it is possible to use them in up to $15-20 \%$ of a wet mixture without negative effects (Hung et al., 2004; Blair, 2008). Composting potato waste is possible 


\begin{tabular}{|c|c|c|c|c|c|c|c|}
\hline \multirow{3}{*}{$\begin{array}{l}\text { BFJ } \\
123,1\end{array}$} & & & & & & & \\
\hline & & & & \multicolumn{2}{|c|}{ Ready-to-eat (chips) } & \multicolumn{2}{|c|}{ Dried potatoes } \\
\hline & & & & $\begin{array}{l}\text { One } t \text { of } \\
\text { final } \\
\text { product }\end{array}$ & $\begin{array}{c}\text { Global Italian } \\
\text { production }\end{array}$ & $\begin{array}{l}\text { One } t \text { of } \\
\text { final } \\
\text { product }\end{array}$ & $\begin{array}{c}\text { Global Italian } \\
\text { production }\end{array}$ \\
\hline \multirow{4}{*}{76} & Material & \multirow{2}{*}{\multicolumn{2}{|c|}{$\begin{array}{l}\text { Seed potatoes }(t) \\
\text { Fertilizers }(t)\end{array}$}} & 0.33 & 21,000 & 0.42 & 160 \\
\hline & input & & & 0.05 & 3,200 & 0.09 & 35 \\
\hline & & \multicolumn{2}{|c|}{ Water $(t)$} & 28 & $1,800,000$ & 61 & 23,400 \\
\hline & & & 0.007 & 450 & 0.015 & 6 \\
\hline & Material & \multicolumn{2}{|c|}{$\begin{array}{l}\text { Transportation energy (toe) } \\
\text { Nonharvested tubers }(t)\end{array}$} & 0.3 & 19,000 & 0.35 & 135 \\
\hline & output & \multicolumn{2}{|c|}{ Uncalibrated tubers $(t)$} & 0.05 & 3,200 & 0.065 & 25 \\
\hline & & \multicolumn{2}{|c|}{ Skins and scraps $(t)$} & 0.35 & 22,200 & 1.6 & 598 \\
\hline & & \multicolumn{2}{|c|}{ Steam $(t)$} & 2.5 & 86,600 & 3.7 & 1,357 \\
\hline & & \multicolumn{2}{|c|}{$\mathrm{CO}_{2}$ emissions (transport) $(t)$} & 0.09 & 5,700 & 0.09 & 35 \\
\hline & & \multicolumn{2}{|c|}{ Final product (unpackaged) $(t)$} & 1 & 63,500 & 1 & 385 \\
\hline & $\begin{array}{l}\text { Monetary } \\
\text { evaluation }\end{array}$ & $\begin{array}{l}\text { Best } \\
\text { scenario }\end{array}$ & $\begin{array}{l}\text { Nonharvested } \\
\text { tubers }(€)\end{array}$ & 57 & $3,610,000$ & 66.5 & 25,577 \\
\hline & & $(190 € / t)$ & Uncalibrated & 9.5 & 608,000 & 12.3 & 4,750 \\
\hline \multirow{3}{*}{$\begin{array}{l}\text { Table } 4 \text {. } \\
\text { Material input, output } \\
\text { and monetary } \\
\text { evaluation in ready-to- } \\
\text { eat and dried potatoes } \\
\text { in Italy (2017) }\end{array}$} & & \multirow{2}{*}{$\begin{array}{l}\text { Worst } \\
\text { scenario } \\
(470 € / t)\end{array}$} & $\begin{array}{l}\text { tubers }(€) \\
\text { Nonharvested } \\
\text { tubers }(€)\end{array}$ & 141 & $8,930,000$ & 164.5 & 63,269 \\
\hline & & & $\begin{array}{l}\text { Uncalibrated } \\
\text { tubers }(€)\end{array}$ & 23.5 & $1,504,000$ & 30.5 & 11,750 \\
\hline & \multicolumn{7}{|c|}{ Source(s): (Personal elaboration by the authors) } \\
\hline
\end{tabular}

on-site with well-known processes, with an average yield of 30-35\% (Ispra, 2002). It is estimated that potato waste compost has a market value of approximately $300 € / t$, with an average production cost equal to $200 € / t$ (Montanati et al., 2017). Potato waste could have several other uses, first among them being bioenergy production such as biogas and bioethanol. Duruyurek et al. (2015) and Izmirlioglu and Demirci (2010) estimated that it is possible with $1 t$ of potato waste to obtain $0.62-0.89 \mathrm{~m}^{3}$ of bioethanol on average, depending on starch content and technology utilized. Average biogas yield has been proven to be approximately $250 \mathrm{~m}^{3}$ for $1 t$ of potato waste. Second, due to the interesting protein content of potato skins, it is possible to reuse them in bakery production, replacing up to $10 \%$ of traditional flour with no organoleptic alterations (Montanati et al., 2017). Moreover, potato waste could be used as an ingredient in health or functional food due to its strong antioxidant activity (Nandita and Rajini, 2004). Green production of lactic acid, widely used in food, pharmaceutical, cosmetic and industrial applications, could be implemented through fermentation and separation of potato waste, with an average yield of $0.140 \mathrm{~kg} / \mathrm{kg}$ of potato skins and an estimated market value of approximately $1.20-1.40 € / \mathrm{kg}$ (RedCorn et al., 2018). With regard to the Italian potatoes industry, the MFA results show that in 2017, approximately 237,500 $t$ of fresh tubers were designated to produce over $63,000 t$ of ready-toeat (chips) potato products and fewer than $400 t$ of dried potatoes. During these productions, more than 22,000 $t$ of fresh tubers were lost because they were not harvested (agricultural stage) or were classified as uncalibrated (processing stage). The consequence was the loss of less than $10 \%$ of cultivated tubers, from which 3,500-4,800 $t$ of starch equivalent and 52,800 $72,600 \mathrm{GJs}$ were also lost in terms of energy value still useful for human consumption. Moreover, fewer than 23,000 $t$ of skins and scraps are produced within industrial plants; this waste is not available for humans but suitable for animal feed, starch industry and bioenergy production (biogas and/or bioethanol). Associated monetary losses are estimated in a range of approximately $€ 4,200,000-10,500,000$, based on potatoes' price at retail of $190-470 € / t$ (ISMEA, 2020). 
Results obtained impose a double consideration. In line with the objective of the analysis, they "measure" food waste in Italian potato industry. Second, they show that it is possible to transform food waste in resources converting costs (disposal costs) into profits. This opportunity requires new approaches where the role of innovation and the sharing capacity is crucial. To this extent, open innovation strategy may represent an example as it has received growing interest from food industry and agrifood system in general (Bigliardi and Galati, 2013). Open innovation is based on the idea that by balancing inflows (inbound open innovation) and outflows (second outbound open innovation) of knowledge the company may create value and remain competitive. Following this model, the company is no longer limited to its core market but may expand toward new market segments. This paradigm can be applied along the whole supply chain, stressing the assumption that the success of a supply chain depends on the level of integration between all players involved. Open innovation strategy, applied to the potato industry from the farm to fork, may open new and more performing scenarios of development in terms of food waste reduction, business opportunity and environmental protection (Ferraris et al., 2017; Fiandrino et al., 2019; Saguy and Sirotinskaya, 2014).

Moreover, MFA also provides background information in aggregated form on the composition and changes of the physical structure of socioeconomics systems for waste management both at country and company level (Bringezu and Moriguchi, 2002; FischerKowalski et al., 2011). The authors, through the analysis of the potato industry, strongly recommend its usage to support communication and facilitate transparency between the various groups engaged in waste management decision-making, both inside and outside the industrial plants (single companies, business networks, government). Its usage represents an interesting way to assess quality and quantity of food waste along the whole food supply chain, in particular at agricultural and processing stage, providing fundamental and transparent knowledge for decision-makers and representing a potential well-grounded inventory for other methodologies (e.g. life cycle assessment), environmental indicators (e.g. carbon and water footprint) and environmental management tools (e.g. ISO 14001 or EMAS) (Allesch and Brunner, 2015). However, to enlarge clarity, comparability and accuracy of its results, the authors recommend well-defined layers (goods and flows) and system boundaries to facilitate results' comprehension to all stakeholders and make possible a wider interaction and knowledge exchange inside and outside companies' perimeter (Ferraris et al., 2017). Moreover, they consider fundamental the right estimation of uncertainties as data gaps and waste coefficients assumptions are inevitable and could potentially compromise final results.

\subsection{Limitations and future research}

One of the main limits of the MFA application is the lack of data - the higher the degree of detail, the better the accuracy of the results. Reliable statistics or data are necessary to build a robust and complete MFA as its results are the basis for translating research (the choice of a reliable food waste measuring tool) into practice (the measurement and reduction of food waste). The analysis proposed is affected by data lack limitations. Energy input required during the processing stage, for instance, is only estimated but not included in the flowcharts because it is not possible to partition it step by step. Oil used in ready-to-eat (chips) production is based on the average potato-to-oil ratio in a continuous frying system presuming that the $100 \%$ of Italian plants utilize it. To increase the robustness and reliability of MFA in the field of food waste measurement and reduction, more efforts are required. Performing, for instance, accounting exercises at different levels (single plant, industrial sector and economic system), it will be possible to reduce the degree of uncertainty affecting actual MFA results. 
$\mathrm{BFJ}$

123,1

These last considerations are strictly connected with future studies. They should be first addressed to improve statistics and data on food production, trade, consumption and food waste generation, with a higher degree of detail (disaggregate data). Later, improving data availability, the MFA methodology will be a very useful tool in food waste measurement, able to offer more complete results to better manage the whole food supply chain, to reduce environmental impacts and to reduce monetary costs associated, overpassing some limits presented by other methodologies (Section 2). Furthermore, the authors are strongly convinced that food waste reduction requires not only efficient measurement tools but also the adoption of useful technologies to improve food safety and food security (e.g. smart packaging or smart storage, irradiation technologies) and adequate communication campaigns to increase consumers' awareness toward the issue. Thus, future lines of research could join the MFA approach along with the role of innovation technologies and the analysis of consumer behavior.

\section{Conclusions}

The present paper supports the use of MFA in the transition toward sustainable management of food waste. Such a methodology offers a highly detailed perspective on the agrifood sector, highlighting hot spots in food production and offering a starting point to evaluate opportunities for reuse, recycling and/or conversion of food waste into energy. The measurement of wastage-related losses of energy, raw materials and monetary resources in each phase of the supply chain represents a fundamental step toward environmental and economic sustainability, suitable both for companies (e.g. breeders, entrepreneurs, service providers, financial institutions) and for policymakers. Therefore, MFA is useful for the following: (1) qualifying and quantifying inputs (raw material, water, energy) required along the whole food supply chain; (2) qualifying and quantifying outputs produced along the food chain, with reference to food waste; (3) highlighting main critical steps (hot spots) along the whole production chain and (4) estimating the amount of losses in natural resources, energy and money related to the food waste phenomenon. Furthermore, the MFA results are perfectly in line with the Agenda 2030 Sustainable Development Goals, supporting, for instance, the creation of a platform where supply of "well-characterized" food waste (what, how much and where) and demand for secondary raw materials could easily be met. The MFA results could represent the basis for the implementation of more efficient and sustainable industrial processes and industrial symbiosis programs, as well as for the construction of environmental indicators (carbon and water footprint) fundamental in the transition toward sustainable and much more circular models in the agrifood sector.

The MFA results could well support managers' and policymakers' strategies. At the managerial level, this mass-balance approach could be used to easily identify deficits in production, improve raw materials' efficiency, develop proactive attitudes toward environmental protection and implement an industrial symbiosis model. For instance, composting $50 \%$ of Italian skins and scraps (more than 11,500 $t$ ) would make it possible to realize an income of 345,000-400,000 € and save more than 11,500-57,500 $€$ in final disposal costs (estimated at 1-5€/t) (Montanati et al., 2017), attaining economic, social and environmental benefits simultaneously. Otherwise, $7,100-10,200 \mathrm{~m}^{3}$ of bioethanol $(28 \mathrm{GJ} / t$ calorific value) could be obtained from $50 \%$ of Italian skins and scraps, avoiding the use of $3,700-5,300 t$ of fossil fuel. At the policymaking level, the MFA results could be used for the introduction of new policies toward the minimization of the food waste issue. Decisionmakers, knowing where, what and how much is produced in terms of food waste, could facilitate matching supply and demand in new markets for food and nonfood sectors, shifting from "zero-value" to "profitable" waste. These policies could decrease food waste disposal and related environmental impacts. 


\section{References}

Abdelaal, A.H., McKay, G. and Mackey, H.R. (2019), "Food waste from a university campus in the Middle East: drivers, composition, and resource recovery potential”, Waste Management, Vol. 98, pp. 14-20.

Allesch, A. and Brunner, P.H. (2015), "Material flow analysis as a decision support tool for waste management. A literature review", Journal of Industrial Ecology, Vol. 19 No. 5, pp. 753-764.

Arslan, M., Xiaobo, Z., Shi, J., Rakha, A., Hu, X., Zareef, M., Zhai, X. and Basheer, S. (2018), “Oil uptake by potato chips or French fries: a review", European Journal of Lipid Science and Technology, Vol. 120 No. 10, 1800058.

Augustin, M.A., Sanguansri, L., Fox, E.M., Cobiac, L. and Cole, M.B. (2020), "Recovery of wasted fruit and vegetables for improving sustainable diets", Trends in Food Science and Technology, Vol. 95 , pp. $75-85$.

Barrett, B. (2010), "Measuring food insecurity", Science, Vol. 327, pp. 825-827.

Barilla Center for Food \& Nutrition (2012), Lo spreco alimentare: cause, impatti e proposte, available at: https://www.barillacfn.com/m/publications/spreco-alimentare-cause-impatti-proposte.pdf (accessed 3 March 2020).

Beretta, C., Stoessel, F., Baier, U. and Hellweg, S. (2013), "Quantifying food losses and the potential for reduction in Switzerland", Waste Management, Vol. 33, pp. 764-773.

Bigliardi, B. and Galati, F. (2013), "Models of adoption of open innovation within the food industry", Trends in Food Science and Technology, Vol. 30 No. 1, pp. 16-26.

Blair, R. (2008), Nutrition and Feeding of Organic Poultry, Cabi Series, CABI, Wallingford.

Boschini, M., Falasconi, L., Giordano, C. and Alboni, F. (2018), "Food waste in school canteens: a reference methodology for large-scale studies", Journal of Cleaner Production, Vol. 182, pp. 1024-1032.

Bräutigam, K.R., Jörissen, J. and Priefer, C. (2014), “The extent of food waste generation across EU-27: different calculation methods and the reliability of their results", Waste Management Resources, Vol. 32, pp. 683-694.

Bringezu, S. and Moriguchi, Y. (2002), "Material flow analysis", in Ayres, R.U., Ayres, L.W. and Ham, C. (Eds), A Hand- Book of Industrial Ecology, Edward Elgar, UK.

Brunner, P.H. and Rechberger, H. (2017), Handbook of Material Flow Analysis. For Environmental, Resource and Waste Engineers, 2nd ed., CRC Press, Taylor \& Francis Group, LLC. Boca Raton, London, New York, NY.

Caldeira, C., De Laurentiis, V., Corrado, S., Van Holsteijn, F. and Sala, S. (2019), "Quantification of food waste per product group along the food supply chain in the European Union: a mass flow analysis", Resources, Conservation, and Recycling, Vol. 149, pp. 479-488.

Camaggio, G. and Lagioia, G. (2002), La trasformazione industriale della patata. Dal tubero al fast food, Quaderno del Dipartimento di Scienze Merceologiche, Progedit, Bari, Vol. 27, pp. 1-56.

Cencic, O. and Kovacs, A., (2007), STAN 2.0 - Software for Substance Flow Analysis. Institut für Wassergüte, Ressourcen management und Abfallwirtschaft, Technische Universität Wien, Karlsplatz, Wien, Vol. 13, p. 1040.

Cicatiello, C., Franco, S., Pancino, B., Blasi, E. and Falasconi, L. (2017), "The dark side of retail food waste_ evidences from in-store data", Resources, Conservation and Recycling, Vol. 125, pp. 273-28.

Delley, M. and Brunner, T. (2018), "Household food waste quantification: comparison of two methods", British Food Journal, Vol. 120, pp. 1504-1515.

De Laurentiis, V., Corrado, S. and Sala, S. (2018), "Quantifying household waste of fresh fruit and vegetables in the EU", Waste Management, Vol. 77, pp. 238-251.

De Marco, O., Lagioia, G., Sgaramella, A. and Amicarelli, V. (2005), "Flusso di materia e ciclo di vita dello zucchero da barbabietola", Atti Del Xxi Congresso Nazionale Di Merceologia - Risorse measure food loss and waste?

, 
BFJ

123,1

Naturali E Sviluppo Economico-Sociale. Contributi delle Scienze Merceologiche, Foggia, 22-24 settembre 2004, Vol. 1, pp. 450-458, ISBN 8884590396, (in collaborazione con G. Lagioia, O. De Marco e A. Sgaramella).

De Marco, O., Lagioia, G., Amicarelli, V. and Sgaramella, A. (2009), "Constructing physical inputoutput tables with material flow analysis (MFA) data: bottom-up case studies", in Sangwon, S. (Ed.), Handbook on Input-Output Economics in Industrial Ecology, Springer Netherlands, pp. 161-187.

De Moraes, C.C., de Oliveira Costa, F.H., Pereira, C.R., da Silva, A.L. and Delai, I. (2020), "Retail food waste: mapping causes and reduction practices", Journal of Cleaner Production, Vol. 256, p. 120124 .

Dias-Ferreira, C., Santos, T. and Oliveira, V. (2015), "Hospital food waste and environmental and economic indicators - a Portuguese case study", Waste Management, Vol. 46, pp. 146-154.

Duruyurek, M., Dusgun, C., Gulhan, M.F. and Selamoglu, Z. (2015), "Production of bioethanol from waste potato", Turkish Journal of Agriculture - Food Science and Technology, Vol. 3 No. 5, pp. 331-334.

Elimelech, E., Ayalon, O. and Ert, E. (2018), "What gets measured gets managed: a new method of measuring household food waste", Waste Management, Vol. 76, pp. 68-81.

Elimelech, E., Ert, E. and Ayalon, O. (2019), "Bridging the gap between self-assessments and measured household food waste: a hybrid valuation approach”, Waste Management, Vol. 95, pp. 259-270.

EPA (2018), "Emission factors for greenhouse gas inventories", available at: https:/www.epa.gov/sites/ production/files/2018-03/documents/emission-factors_mar_2018_0.pdf (accessed 28 Feburary 2020).

Eriksson, D., Carlson-Nilsson, U., Ortíz, R. and Andreasson, E. (2016), "Overview and breeding strategies of table potato production in Sweden and the fennoscandian region", Potato Research, Vol. 59 No. 3, pp. 279-294.

Eriksson, M., Osowski, C.P., Malefors, C., Björkman, J. and Eriksson, E. (2017), "Quantification of food waste in public catering services - a case study from a Swedish municipality", Waste Management, Vol. 61, pp. 415-422.

EssonanaweEdjabou, M., Petersen, C., Scheutz, C. and Fruergaard Astrup, T. (2016), "Food waste from Danish households: generation and composition", Waste Management, Vol. 52, pp. 256-268.

European Commission (2007), The Potato Sector in the European Union Commission Staff Working Document SEC 2007533 Brussels 20.04.2007, pp. 1-118, available at: https://op.europa.eu/en/ publication-detail/-/publication/aa7a3bf1-af37-475d-8ff6-9578cc267a43/language-en (accessed 27 February 2020).

European Commission (2010), Preparatory Study on Food Waste across EU27, available at: https:/ec. europa.eu/environment/archives/eussd/pdf/bio_foodwaste_report.pdf (accessed 27 February 2020).

Eurostat (2020), Crop Production in EU Standard Humidity, available at: https://data.europa.eu/ euodp/en/data/dataset/u33K8Gi1MFYGN7HyHUNhg (accessed 30 April 2020).

Fabi, C. and English, A. (2018), Methodological Proposal for Monitoring SDG Target 12.3: The Global Food Loss Index Design, Data Collection Methods and Challenges, FAO, Rome.

FAO (2011), Global Food Losses and Food Waste: Extent, Causes and Prevention, FAO, Rome.

FAO (2017), Global Initiative on Food Loss and Waste", Food and Agriculture Organization of the United States, Rome.

FAO (2018), World Food and Agriculture - Statistical Pocketbook 2018, Food and Agriculture Organization of the United States, Rome.

FAO (2019a), "Background: technical platform on the measurement and reduction of food loss and waste", available at: http://www.fao.org/platform-food-loss-waste/en/ (accessed 27 February 2020).

FAO (2019b), State of Food and Agriculture, FAO, Rome. 
FAO (2019c), The State of Food and Agriculture 2019. Moving Forward on Food Loss and Waste Reduction, Licence, Rome, CC BY-NC-SA 3.0 IGO.

FAO, IFAD, UNICEF, WFP and WHO (2018), The State of Food Security and Nutrition in the World 2018. Building Climate Resilience for Food Security and Nutrition, Food and Agriculture Organization of the United States, Rome.

FAOSTAT (2019), Crops, 2017, available at: http://www.fao.org/faostat/en/\#data/QC (accessed 27 February 2020).

Ferraris, A., Santoro, G. and Bresciani, S. (2017), 'Open innovation in multinational companies' subsidiaries: the role of internal and external knowledge", European Journal of International Management, Vol. 11 No. 4, pp. 452-468.

Fiandrino, S., Busso, D. and Vrontis, D. (2019), "Sustainable responsible conduct beyond the boundaries of compliance. Lessons from Italian listed food and beverage companies", British Food Journal, Vol. 121 No. 5, pp. 1035-1049.

Fiore, M., Contò, F. and Pellegrini, G. (2015), "Ridurre le perdite alimentari: un modello di costo (dis)opportunità", Rivista di Studi Sulla Sostenibilità, Vol. 1, 2015, pp. 151-166.

Fiore, M., Pellegrini, G., La Sala, P., Conte, A. and Liu, B. (2017), "Attitude toward food waste reduction: the case of Italian consumers", International Journal of Globalisation and Small Business, Vol. 9, pp. 185-201.

Fischer-Kowalski, M., Krausmann, F., Giljum, S., Lutter, S., Mayer, A., Bringezu, S., Moriguchi, Y., Schutz, H., Schandl, H. and Weisz, H. (2011), "Methodology and indicators of economy-wide material flow accounting", Journal of Industrial Ecology, Vol. 15 No. 6, pp. 855-876.

FUSIONS (2014), Report on Review of (Food) Waste Reporting Methodology and Practice, Krakerøy, Norway.

FUSIONS (2016a), Estimates of European Food Waste Levels, available at: https://www.eu-fusions. org/phocadownload/Publications/Estimates $\% 20$ of $\% 20$ European $\% 20$ food $\% 20$ waste $\% 20$ levels .pdf (accessed 3 March 2020).

FUSIONS (2016b), Market-based Instruments and Other Socio-Economic Incentives Enhancing Food Waste Preventing and Reduction, available at: https://www.eu-fusions.org/index.php/ download?download\%C2\%BC\%20219:d33a-market-based-instrument (accessed 3 March 2020).

Galanakis, C.M. (2020), "Food waste valorization opportunities for different food industries", in Galanakis, C.M. (Ed.), The Interaction of Food Industry and Environment, Academic press, London.

Galati, A., Moavero, P. and Crescimanno, M. (2019), "Consumer awareness and acceptance of irradiated foods: the case of Italian consumers", British Food Journal, Vol. 121 No. 6, pp. 1398-1412.

Galford, G.L., Peña, O., Sullivan, A.K., Nash, J., Gurwick, N., Pirolli, G., Richards, M.X., White, J. and Wollenberg, E. (2020), "Agricultural development addresses food loss and waste while reducing greenhouse gas emissions", The Science of the Total Environment, Vol. 699, p. 134318.

Garcia-Garcia, G., Stone, J. and Rahimifard, S. (2019), "Opportunities for waste valorisation in the food industry - a case study with four UK food manufacturers", Journal of Cleaner Production, Vol. 211, pp. 1339-1356.

Giordano, C., Piras, S., Boschini, M. and Falasconi, L. (2018), “Are questionnaires a reliable method to measure food waste? A pilot study on Italian households", British Food Journal, Vol. 120, pp. 2885-2897.

Goodman-Smith, F., Mirosa, M. and Skeaff, S. (2020), "A mixed-methods study of retail food waste in New Zealand”, Food Policy, Vol. 92, p. 101845.

Gustavsson, J., Cederberg, C., Sonesson, U., Van Otterdijk, R. and Meybeck, A. (2011), Global Food Losses and Food Waste. Extent, Causes and Prevention, Food and Agriculture Organization of the United Nations (FAO), Rome. 
$\mathrm{BFJ}$ 123,1

Hung, Y.T., Lo, H.H., Awad, A. and Salman, H. (2004), "Potato wastewater treatment", in Wang, L.K., Hung, Y.T., Howard, H., Lo, H.H. and Yapijakis, C. (Eds.), Waste Treatment Food Processes India, 1st ed., Taylor \& Francis Group, LLC, Boca Raton, pp. 193-254.

International Food Policy Research Institute (2019), 2019 Global Food Policy Report, International Food Policy Research Institute, Washington, DC, available at: https://www.ifpri.org/publication/ 2019-global-food-policy-report (accessed 27 February 2020).

ISMEA (2003), L'industria Di Trasformazione Della Patata, Quaderni Di Filiera N., ISMEA, Roma, Vol. 7, pp. 1-58.

ISMEA (2020), Osservatorio Patate. Prezzi Allorigine. Trend Annui, available at: http://www. ismeamercati.it/osservatorio-patate\#MenuV (accessed 3 March 2020).

Ispra (2002), Il recupero di sostanza organica dai rifiuti per la produzione di ammendanti di qualità, Ispra, Roma.

Istat (2014), $6{ }^{\circ}$ Censimento Generale dell'Agricoltura. Utilizzo Della Risorsa Idrica a Fini Irrigui in Agricoltura, Ispra, Roma.

Istat (2020a), Coltivazioni: Cereali, legumi, radici bulbi e tuberi, 2017, Istat, available at: http://dati.istat. it/Index.aspx?QueryId=33702\# (accessed 25 February 2020).

Istat (2020b), Produzione industriale in quantità e valore: Prodotti alimentari e tabacco, 2017, Istat, available at: http://dati.istat.it/Index.aspx?QueryId=8910 (accessed 13 March 2020).

Izmirlioglu, G. and Demirci, A. (2010), "Ethanol production from waste potato mash by using Saccharomyces cerevisiae", Applied Sciences, Vol. 2 No. 4, pp. 738-753.

Jacobi, N., Haas, W., Wiedenhofer, D. and Mayer, A. (2018), "Providing an economy-wide monitoring framework for the circular economy in Austria: status quo and challenges", Resources, Conservation and Recycling, Vol. 137, pp. 156-166.

Janssens, S.R.M., Wiersema, S.G., Goos, H. and Wiersma, W. (2013), "The value chain for seed and ware potatoes in Kenya. Opportunities for development", LEI Memorandum 13-080, LEI Wageningen UR, Den Haag, NL, pp. 1-57.

Ju, M., Osako, M. and Harashina, S. (2017), "Food loss rate in food supply chain using material flow analysis", Waste Management, Vol, 61, pp. 443-454.

Kasza, G., Szabó-Bódi, B., Lakner, Z. and Izsó, T. (2019), "Balancing the desire to decrease food waste with requirements of food safety", Trends in Food Science and Technology, Vol. 84, pp. 74-76.

Katajajuuri, J.M., Silvennoinen, K., Hartikainen, H., Heikkilä, L. and Reinikainen, A. (2014), "Food waste in the Finnish food chain”, Journal of Cleaner Production, Vol. 73, pp. 322-329.

Kytzia, S., Faist, M. and Baccini, P. (2004), "Economically extended-MFA: a material flow approach for a better understanding of food production chain”, Journal of Cleaner Production, Vol. 12 Nos 8-10, pp. 877-889.

Lagioia, G., Amicarelli, V., Stifani, S. and De Marco, O. (2005), "L’Analisi dei flussi di materia nel settore zootecnico italiano", Atti del XXI Congresso Nazionale di Merceologia-Risorse naturali e sviluppo economico-sociale, Contributi delle Scienze Merceologiche, Foggia, 22-24 settembre 2004, Vol. 1, pp. 102-111, ISBN 8884590396. (in collaborazione con G. Lagioia, O. De Marco e S. Stifani). 
Lagioia, G., Calabrò, G. and Amicarelli, V. (2012), "Empirical study of the environmental management of Italy's drinking water supply”, Resources, Conservation and Recycling, Vol. 60, pp. 119-130.

Lagioia, G., Amicarelli, V., Gallucci, T. and Bux, C. (2020), "Food loss and waste reduction towards food sector sustainability", in Erokhin, V. and Gao, T. (Eds), Handbook of Research on Globalized Agricultural Trade and New Challenges for Food Security, IGI Global, Hershey, PA, pp. 1-475.

Lebersorger, S. and Schneider, F. (2011), "Discussion on the methodology for determining food waste in household waste composition studies", Waste Management, Vol. 31 No. 9, pp. 1924-1933.

Love, D.C., Fry, J.P., Milli, M.C. and Neff, R.A. (2015), "Wasted seafood in the United States: quantifying loss from production to consumption and moving toward solutions", Global Environmental Change, Vol. 35, pp. 116-124.

Martin-Rios, C., Demen-Meier, C., Gössling, S. and Cornuz, C. (2018), "Food waste management innovations in the foodservice industry", Waste Management, Vol. 79, pp. 196-206.

McCarthy, U., Ismail, U., Badia-Melis, R., Mercier, S.O., Donnell, C. and Ktenioudaki, A. (2018), "Global food security. Issues, challenges and technological solutions", Trends in Food Science and Technology, Vol. 77, pp. 11-20.

MIPAAF (2012), "Piano di settore per la filiera pataticola", available at: https://www.politicheagricole. it/flex/cm/pages/ServeBLOB.php/L/IT/IDPagina/5144 (accessed 27 February 2020).

Monier, V., Mudgal, S., Escalon, V., O'Connor, C., Gibon, T. and Anderson, G. (2010), Preparatory Study on Food Waste across EU27, Final report, European Commission, Brussels.

Montanati, A., Cigognini, I.M. and Cifarelli, A. (2017), Agri and Food Waste Valorisation Co-ops Based on Flexible Multi-Feedstocks Biorefinery Processing Technologies for New High Added Value Applications, available at: http://agrimax-project.eu/files/2017/05/AgriMAX-StakeholderWorkshop-Proceedings_final.pdf (accessed 27 February 2020).

Mouron, P., Willersinn, C., Möbius, S. and Lansche, J. (2016), "Environmental profile of the Swiss supply chain for French fries: effects of food loss reduction, loss treatments and process modifications", Sustainability, Vol. 8 No. 12, p. 1214.

Nahman, A., de Lange, W., Oelofse, S. and Godfrey, L. (2012), "The costs of household food waste in South Africa”, Waste Management, Vol. 32, pp. 2147-2153.

Nandita, S. and Rajini, P.S. (2004), "Free radical scavenging activity of an aqueous extract of potato peel", Food Chemistry, Vol. 85, pp. 611-616.

Ng, H., Kee, P.E., Yim, H.S., Chen, P.T., Wei, Y.W. and Lan, J.C.W. (2020), "Recent advances on the sustainable approaches for conversion and reutilization of food wastes to valuable bioproducts”, Bioresource Technology, Vol. 302, p. 122889.

Notarfonso, M., Coppola, G. and Farina, S. (2015), Food recovery and waste reduction foodward project progetto sul recupero e la riduzione degli sprechi alimentari, available at: http://www.federal imentare.it/informalimentare/informalimentare_6_2015-FOODWARDPROJECT.pdf (accessed 27 February 2020).

OJEU (Official Journal of the European Union (2019), Commission Delegated Decision (EU) 2019/1597 of 3 May 2019, available at: https://eur-lex.europa.eu/legal-content/EN/TXT/?uri=OJ:L:2019: 248:TOC (accessed 17 March 2020).

Parfitt, J., Barthel, M. and Macnaughton, S. (2010), Food Waste within Food Supply Chains: Quantification and Potential for Change to 2050, Philosophical transactions of the Royal Society of London, Series B, Biological sciences, Vol. 365, pp. 3065-3081.

Parizeau, K., von Massow, M. and Martin, R. (2015), "Household-level dynamics of food waste production and related beliefs, attitudes, and behaviours in Guelph, Ontario", Waste Management, Vol. 35, pp. 207-217.

Pellegrini, G., Sillani, S., Gregori, M. and Spada, A. (2019), "Household food waste reduction: Italian consumers' analysis for improving food management”, British Food Journal, Vol. 121, pp. 1382-1397. 
BFJ 123,1

\section{4}

Philippidis, G., Sartori, M., Ferrari, E. and M'Barek, R. (2019), "Waste not, want not: a bio-economic impact assessment of household food waste reductions in the EU", Resources, Conservation and Recycling, Vol. 146, pp. 514-522.

Poças Ribeiro, A., Rok, J., Harmsen, R., Carreón, J.R. and Worrell, E. (2019), "Food waste in an alternative food network - a case-study", Resources, Conservation and Recycling, Vol. 149, pp. 210-219.

Read, Q.D., Brown, S., Cuéllar, A.D., Finn, S.M., Gephart, J.A., Marston, J.T., Meyer, E., Weitz, K.A. and Muth, M.K. (2019), "Assessing the environmental impacts of halving food loss and waste along the food supply chain”, The Science of the Total Environment, Vol. 685, pp. 1240-1254.

Read, Q.D., Brown, S., Cuéllar, A.D., Finn, S.M., Gephart, J.A., Marston, L.T., Meyer, E., Weitz, K.A. and Muth, M.K. (2020), "Assessing the environmental impacts of halving food loss and waste along the food supply chain”, The Science of the Total Environment, Vol. 712, p. 136255.

RedCorn, R., Fatemi, S. and Engelberth, A.S. (2018), "Comparing end-use potential for industrial foodwaste sources", Engineering, Vol. 4, pp. 371-380.

Risku-Norja, H. and Mäenpää, I. (2007), "MFA model to assess economic and environmental consequences of food production and consumption", Ecological Economics, Vol. 60 No. 4, pp. 700-711.

Sablani, S. and Mujumdar, A. (2006), "Drying of potato, sweet potato, and other roots", Handbook of Industrial Drying, 4th ed., Taylor \& Francis Group, LLC, Boca Raton.

Saguy, I.S. and Sirotinskaya, V. (2014), "Challenges in exploiting open innovation's full potential in the food industry with a focus on small and medium enterprises (SMEs)", Trends in Food Science and Technology, Vol. 38 No. 2, pp. 136-148.

Sakaguchi, L., Pak, N. and Potts, M.D. (2018), "Tackling the issue of food waste in restaurants: options for measurement method, reduction and behavioral change", Journal of Cleaner Production, Vol. 180, pp. 430-436.

Sansano, M., Juan-Borrás, M., Escriche, I., Andres, A. and Heredia, A. (2015), "Effect of pretreatments and AirFrying, a novel technology, on acrylamide generation in fried potatoes", Journal of Food Science, Vol. 80, pp. 1120-1128.

Schneider, F., Part, F., Göbel, C., Langen, N., Gerhards, C., Kraus, G.F. and Ritter, G. (2019), "A methodological approach for the on-site quantification of food losses in primary production: Austrian and German case studies using the example of potato harvest", Waste Management, Vol. 86, pp. 106-113.

Setti, M., Banchelli, F., Falasconi, L., Segrè, A. and Vittuari, M. (2018), "Consumers' food cycle and household waste. When behaviors matter", Journal of Cleaner Production, Vol. 185, pp. 694-706.

Sharp, V., Giorgi, S. and Wilson, D.C. (2010), "Methods to monitor and evaluate household waste prevention”, Waste Management and Research, Vol. 28 No. 3, pp. 269-280.

Silvennoinen, L.H., Katajajuuri, J.M. and Reinikainen, A. (2015), "Food waste volume and origin: case studies in the Finnish food service sector", Waste Management, Vol. 46, pp. 140-145.

Silvennoinen, K., Nisonen, S. and Pietiläinen, O. (2019), "Food waste case study and monitoring developing in Finnish food services”, Waste Management, Vol. 97, pp. 97-104.

Szabó-Bódi, B., Kasza, G. and Szakos, D. (2018), "Assessment of household food waste in Hungary", British Food Journal, Vol. 120, pp. 625-638.

Tarabella, A., Masoni, A., Trivelli, L., Apicella, A., Lombardi, M., Rana, R.L. and Tricase, C. (2019), "Innovation in the food industry: a comparison between new and traditional categories of foodstuffs", Food Products Evolution: Innovation Drivers and Market Trends. SpringerBriefs in Food, Health, and Nutrition, Springer, Cham.

Thamagasorn, M. and Pharino, C. (2019), "An analysis of food waste from a flight catering business for sustainable food waste management: a case study of halal food production process", Journal of Cleaner Production, Vol. 228, pp. 845-855. 
Tostivint, C., de Veron, S., Jan, O., Lanctuit, H., Hutton, Z.H. and Loubière, M. (2017), "Measuring food waste in a dairy supply chain in Pakistan", Journal of Cleaner Production, Vol. 145, pp. 221-231.

Van Dooren, C., Janmaat, O., Snoek, J. and Schrijnen, M. (2019), "Measuring food waste in Dutch households: a synthesis of three studies", Waste Management, Vol. 94, pp. 153-164.

van Herpen, E., van der Lans, I., Nijenhuis-de Vries, M., Holthuysen, N., Kremer, S. and Stijnen, D. (2016), "Consumption Life Cycle Contributions - Assessment of Practical Methodologies for InHome Waste Measurement", Wageningen University, Netherlands.

van Herpen, E., van der Lans, I.A., Holthuysen, N., Nijenhuis-de Vries, M. and Quested, T.E. (2019), "Comparing wasted apples and oranges: an assessment of methods to measure household food waste", Waste Management, Vol. 88, pp. 71-84.

Willersinn, C., Mack, G., Mouron, P., Keiser, A. and Siegrist, M. (2015), "Quantity and quality of food losses along the Swiss potato supply chain: stepwise investigation and the influence of quality standards on losses", Waste Management, Vol. 46, pp. 120-132.

World Hunger Education Service (2016), "Food Loss and Waste in the United States and Worldwide", available at: https://www.worldhunger.org/food-loss-and-waste-in-the-united-states-and-worldwide/ (accessed 25 February 2020).

Zaghdaoui, H., Jaegler, A., Gondran, N. and Montoya-Torres, J. (2017), "Material flow analysis to evaluate sustainability in supply chains", 20th World Congress the International Federation of Automatic Control, July 2017, Toulouse, France.

\section{Corresponding author}

Vera Amicarelli can be contacted at: vera.amicarelli@uniba.it

For instructions on how to order reprints of this article, please visit our website:

www.emeraldgrouppublishing.com/licensing/reprints.htm

Or contact us for further details: permissions@emeraldinsight.com 